\title{
Violência de gênero no município de Seropédica/RJ: delimitações sobre o "perfil" da
}

\section{violência}

\author{
Gender violence in the city of Seropédica/RJ: delimitations on the "profille" of violence \\ Violencia de género en la ciudad de Seropédica/RJ: delimitaciones sobre el "perfil" de la violencia
}

Recebido: 04/02/2022 | Revisado: 09/02/2022 | Aceito: 13/02/2022 | Publicado: 20/02/2022

\author{
Vinicius Ferreira Baptista \\ ORCID: https://orcid.org/0000-0002-8717-8332 \\ Universidade Federal Rural do Rio de Janeiro, Brasil \\ E-mail: viniciusferbap@ufrrj.br
}

\begin{abstract}
Resumo
O presente trabalho investiga um possível "perfil" da violência contra a mulher no município de Seropédica/RJ em diferentes arcos temporais no período de 2006 e 2019. Para sua interpretação, partimos de bases teóricas que permitem elaborar um sentido de violência contra a mulher como uma das manifestações da violência de gênero. Paralelamente, apresentamos a legislação e ação governamental do município para identificar como a temática se desenvolve governamentalmente, ao passo em que cotejamos os bancos de dados sobre a violência de gênero em Seropédica. O sentido do trabalho permite subsidiar ao gestor público um "perfil" que compreenda uma forma de violência construída pela proximidade da relação entre a vítima e agressor, além de sua "invisibilidade" do local em que ocorre. Igualmente, existe um contexto claro de violência que não é objeto de consideração nem de intervenção do Estado (neste caso, do município), ao passo em que existem mecanismos institucionais de mera "aparência" governamental.
\end{abstract}

Palavras-chave: Gênero; Violência contra a mulher; Seropédica; Políticas públicas; Violência.

\begin{abstract}
The present work investigates a possible "profile" of violence against women in the municipality of Seropédica/RJ in different time arcs between 2006 and 2019. For its interpretation, we start from theoretical bases that allow us to elaborate a sense of violence against women as one of the manifestations of gender violence. At the same time, we present the legislation and governmental action of the municipality to identify how the theme develops governmentally, while comparing the databases on gender violence in Seropédica. The sense of work allows the public manager to subsidize a profile that comprises a form of violence built by the proximity of the relationship between the victim and the aggressor, in addition to their "invisibility" of the place where it occurs. Likewise, there is a clear context of violence that is not the object of consideration or intervention by the State (in this case, the municipality); while there are institutional mechanisms of mere governmental "appearance".
\end{abstract}

Keywords: Gender; Violence against women; Seropédica; Public policy; Violence.

\section{Resumen}

El presente trabajo investiga un posible "perfil" de la violencia contra la mujer en la ciudad de Seropédica/RJ en diferentes arcos temporales entre 2006 y 2019. Para su interpretación, partimos de bases teóricas que nos permitan elaborar un sentido de la violencia contra la mujer como uno de las manifestaciones de violencia de género. Al mismo tiempo, presentamos la legislación y acción gubernamental del municipio para identificar cómo se desarrolla el tema gubernamentalmente, mientras cotejamos las bases de datos sobre violencia de género en Seropédica. El sentido de la obra permite al gestor público subsidiar un perfil que comprende una forma de violencia construida por la proximidad de la relación entre víctima y agresor, además de su "invisibilidad" desde el lugar donde se produce. Asimismo, existe un claro contexto de violencia que no es objeto de consideración o intervención por parte del Estado (en este caso, del municipio), mientras que existen mecanismos institucionales de mera "apariencia" gubernamental.

Palabras clave: Género; Violencia contra las mujeres; Seropédica; Políticas públicas; Violencia.

\section{Introdução}

O objetivo do trabalho investigar o perfil da violência contra a mulher no município de Seropédica, no estado do Rio de Janeiro ao longo do ano de 2019, também considerando o arco de 2006 a 2019. O sentido do trabalho se dá na necessidade de se materializar críticas e sugestões à produção de dados e interpretações acerca do perfil que permitam subsidiar ao gestor público de informações para projeção de políticas públicas. 
Dividimos, assim, o texto em seis sessões: na primeira, argumentamos as bases teóricas que permitem construir um sentido de violência de gênero, especificando a violência contra a mulher como uma de suas manifestações, ao passo em que organizamos elementos de suporte à interpretação do perfil da violência; em seguida, destacamos a legislação, as interpretações e ação institucional no município de Seropédica/RJ na temática apresentada; na terceira sessão, apresentamos as ações, programas e plano plurianual para identificar como a temática se desenvolve governamentalmente; a penúltima sessão traz os dados sobre a violência de gênero no município de Seropédica. Por fim, apresentamos nossas considerações finais.

A violência contra a mulher é configurada em três perspectivas: 1) historicamente construído em mecanismos de subordinação, assujeitamento e dominação; 2) saúde pública, enquanto constante epidêmica de altos índices que colocam o Brasil como um dos locais mais propícios à violência de gênero; 3) violação de direitos humanos calcado na base estrutural da ordem social. Esta forma de violência se constrói pela proximidade da relação entre a vítima e agressor, além de sua "invisibilidade" do local em que ocorre, ao mesmo tempo em que se solidifica pela moralidade com a qual é tratada. Por fim, a violência contra a mulher tem uma característica ainda mais específica: a de possuir um rosto. A relação entre vítima e agressor é conhecida. Aqui existem duas implicações: 1) a relação de subordinação, propriedade e honra; 2) a resistência à moralidade da violência.

Por fim, ainda há de se considerar as incongruências do município de Seropédica: destacamos que os dados, as instituições e os programas falam - existe um contexto claro de violência que não é objeto de consideração nem de intervenção do Estado (neste caso, do município), ao passo em que existem mecanismos institucionais de mera "aparência" governamental.

\section{Metodologia}

As principais referências metodológicas são contidas em Richardson et al (2007), que nos orientam esta pesquisa como de natureza aplicada, com abordagem qualitativa, objetivo explicativo e uso de procedimentos bibliográficos e documentais. Os dados relativos a Seropédica foi solicitada na plataforma do ISP Dados em abril de 2020, por meio da qual foi obtida uma planilha ${ }^{1}$. O arquivo contém os dados relativos aos crimes de ameaça, estupro, lesão corporal, tentativa de homicídio, homicídio doloso, extorsão, sequestro e feminicídio, entretanto, não vieram desagregados por tal, apesar de solicitados. Os dados estão, portanto, agregados no âmbito dos crimes, existindo estratificação no âmbito do local do crime, sexo, cor, profissão, relação, idade e lei de aplicação (este apenas a partir de $1^{\circ}$ de maio de 2012).

\section{Os Aportes Teóricos de uma Violência Institucional Contra a Mulher}

Maria Araújo (2008) sintetiza a "violência contra a mulher" em dois elementos confluentes e estruturais: poder e dominação. Costuma-se associar este tipo de violência com a violência ocorrida em ambiente doméstico, assim como ligá-lo à violência de gênero. É a partir da década de 1980, no contexto dos espancamentos conjugais, maus-tratos e demais violências contra a mulher, que este termo se associa como sinônimo de violência doméstica, notadamente pelo fato de a maior parte das vítimas serem mulheres.

Lourdes Bandeira (2014, p. 449) destaca que é ao longo da década de 1980 que estudos sobre a violência de gênero "constituem-se em um campo teórico-metodológico fundado a partir das reivindicações do movimento feminista brasileiro e internacional". Este campo e desenvolveu na medida em que desconstruía elementos "naturais" das relações de gênero, da inferiorização da mulher e subordinação nas relações sociais entre homens e mulheres. Lima et al (2016, p. 140) entendem que este tipo de violência "tem raízes na discriminação, na visão de que a mulher é frágil e submissa ao homem".

Heleieth Saffioti e Suely Almeida (1995), por outro lado, entendem como mais adequado o uso do termo "violência

\footnotetext{
${ }^{1}$ Ver em http://www.ispdados.rj.gov.br/.
} 
de gênero" referindo-se à conceito mais amplo que "violência contra a mulher", abrangendo crianças e adolescentes, também objetos da violência masculina, sendo constitutiva das relações de gênero no Brasil. Portanto, violência contra a mulher é uma das fundamentais formas de violência de gênero. Bandeira (2014, p. 451) também segue este raciocínio, ao apontar que o termo violência de gênero remete "ações violentas são produzidas em contextos e espaços relacionais" sobre a mulher, "tanto no âmbito privado-familiar como nos espaços de trabalho e públicos".

Para Araújo (2008) as relações de poder se produzem e reproduzem no contexto da violência de gênero, como uma medida estrutural das relações sociais ampliadas "mediatizada pela ordem patriarcal, que delega aos homens o direito de dominar e controlar suas mulheres" (Araújo, 2008, s/p). Iris Young (1990, 2010, 2011) entende que a produção da violência de gênero, como parte das representações de gênero, engendra a base da estrutura social que oprime as mulheres e orienta mecanismos de segregação, hierarquização e oportunidades sociais que incidem sobre as vidas das mesmas, produzindo e reproduzindo contextos opressores que privilegiam os homens.

Existem registros de menção da violência contra a mulher desde 1950, em nível internacional, a respeito das decorrências ocasionadas nas vítimas, a exemplo de vulnerabilidade social, estresse pós-traumático, depressão e suicídio (Michau et al, 2015). Ao mesmo tempo, para White et al., (2015) este tipo de violência é caracterizado por um padrão de comportamento que pode envolver agressões físicas com o uso de armas ou não, assim como atos morais e sexuais contra a vítima e abusos psicológicos, financeiros e de proibição de convivência da mulher, cujo foco é o desenvolvimento de relação de dependência e controle.

O espaço doméstico e familiar é o lugar onde ocorrem as agressões e o agressor alguém que mantém ou manteve com a vítima uma relação de proximidade e intimidade, onde a violência física é a mais frequente ou denunciada, seguida da psicológica e sexual, em que prevalecem como fatores preponderantes "a relação de poder que o homem tem sobre a mulher e que lhe dá o "direito" de agredi-la por qualquer motivo" (Araújo, 2008, s/p).

Aqui, Joan Scott (1988) entende que o sujeito masculino não deve ser entendido como sujeito absoluto do poder e da violência, mas que a categoria "gênero" permite compreender os contextos e momentos históricos na base situacional do exercício das relações der poder. Assim, as mulheres não são interpretadas como sujeitos passivos das relações, subordinadas eternamente aos contextos de violência, incapazes de sair da dimensão de abuso.

Neste sentido, Leila Garcia (2016) observa um fato dos homens na relação da violência: o predomínio, tanto como vítimas, quanto como perpetradores, ou seja, sujeitos ativos e passivos da dimensão da violência. Obviamente, que em diferentes contextos. Em 2011, os homens foram as principais vítimas $(75,1 \%)$ e agressores $(83,1 \%$ e $69,7 \%$ dos casos de violência perpetrada contra vítimas do sexo masculino e feminino, respectivamente). Em vias públicas, os homens são as principais vítimas de formas de violência. No caso da violência contra a mulher, a características é a invisibilidade de uma violência perpetrada por familiares e conhecidos balizando relações desiguais de justiça e reconhecimento e que se orienta em dinâmicas de espaços e territórios que reduzem agência das mulheres (Baptista, 2020; Baptista, 2021b; Baptista \& Santos, 2021c).

Garcia (2016) aponta que a violência contra a mulher é considerado problema de saúde pública de proporções epidêmicas no Brasil, uma vez que os contextos de subnotificação por conta do não registro dos fatos, dos mecanismos de subordinação e controle existentes nas relações familiares, a influência das redes pessoais em não denunciar cônjuges, por exemplo, implicam dados distantes da realidade social que coloca a mulher como alvo critico de violência em ambiente que acaba por se tornar intransponível ao Estado. O que se perceve é que para uma construção de cenários próximos da realidade depende da qualidade das informações e, neste caso, como o informe depende da compreensão da vítima e da interpretação do agente de segurança, os parâmetros normativos do que se orienta por violência são críticos (Battisti \& Lohmann, 2020).

Esse elemento instransponível tem relação com um dos maiores desafios dos movimentos feministas frente à base 
legal punitiva do combate a violência de gênero: a legitimação da violência pela noção da honra das relações conjugais e à passionalidade dos crimes cometidos ou ao uso da manipulação moral e caráter negativo da mulher, associando o sentido da violência contra a mulher também como uma violência moral, nos termos de Rita Segato (2003). Bandeira (2014) situa que os assassinatos de mulheres permanecem sendo praticados e têm aumento significativo, conquanto não sejam mais esclarecidos oficialmente como crimes de honra.

Assim, ainda que os crimes de honra não sejam mais tipificados juridicamente, a mudança de justificativa não alterou o tipo de crime para Bandeira (2014, p. 457), já que "a manutenção da lógica familista alia-se aos motivos aparentemente desencadeadores da violência e que são sempre frequentes nas conciliações dos conflitos domésticos e intrafamiliar". Segato (2003) complementa, ponderando que as relações sociais de convivência nos lócus privado e familiar propiciam a instalação da violência de gênero, assim como a sua potência. Portanto, há de ser considerada a crítica de que leis meramente de alcance punitivo estritamente pelas vias penais de reclusão são incapazes de alterar a cultura de violência intrafamiliar e substituir por uma cultura de paz (Cordeiro et al, 2020).

Ainda que tenhamos a perspectiva brasileira, a Organização Mundial da Saúde (2013), aponta que a violência contra a mulher é um problema epidêmico mundial, indistinto de marcadores sociais, como classe, raça e sexualidade (ainda que estes tenham a possibilidade de interferir como marcador que potencialize a violência, quando comparados entre outras vítimas). Para a agência internacional, 35\% das mulheres em todo o mundo são vítimas de violência física e/ou sexual cometida na maior parte por pessoas de conhecimento da vítima e de relações próximas. É, desta forma, que a dimensão da violência contra a mulher delimita contornos internacionais (Sebaldeli; Ignotti \& Hartwig, 2021) em que as dinâmicas socioculturais associadas à violência alcançam as mulheres ao longo de sua vida e em várias esferas além da doméstica ou das relações íntimas (Silva et al, 2020).

Barufaldi et al (2017) trazem dados que contextualizam este delito: no período de 2011 a 2015, o número total das notificações de violências mais do que dobrou, passando de 107.530 para 242.347. A maioria dos homicídios foi por arma de fogo (49\%), sendo que das 567.456 mulheres vítimas de violência que foram notificadas, entre 2011 e 2015, 2.599 vieram a óbito por agressão, em que 54,7\% em mulheres negras, seguidas de brancas $(42,4 \%)$, ao passo em que 15,9\% tinham história prévia de violência de repetição, com destaque para as adultas $(17,7 \%)$ e a residência o local de maior ocorrência da violência $(48,1 \%)$.

Safiotti (2004) interpreta este fenômeno como problema de saúde pública e enraizado nas manifestações mais derradeiras e cruéis da desigualdade de gênero que conforma clara violação dos direitos humanos. Henry Steiner (2000), a partir de sua compreensão sobre violação de direitos humanos, nos permite interpretar a violência de gênero como violação de direitos humanos de caráter estrutural e institucional, situado na organização das relações sociais e que delimita a vida as mulheres ao contexto violento sem defesa (Baptista, 2021a).

Neste ponto, Barufaldi et al (2017, p. 2937) entendem que o "conhecimento do perfil das notificações e da mortalidade por violência contra a mulher é fundamental para traçar estratégias de enfretamento deste problema de saúde pública", o que também é defendido por Lima et al (2016). Este fato é reforçado por Safiotti (2004), Segato (2003), Bandeira (2014), Araújo (2008), Silva et al., (2020) e Garcia (2016), ao apontarem que a subnotificação, as ameaças às denúncias e o controle moral das relações de poder de proximidade da vítima comportam na construção da invisibilidade da violência de gênero, especificamente da violência contra a mulher. Assim, a produção de estatísticas e estudos sobre a violência contra a mulher precisam incorporar dimensões de estratificação que orientam compreensão dos cenários de violência. 


\section{Violência Contra a Mulher: Legislação, Interpretações e Ação Institucional no Município de Seropédica/RJ}

Em 2007, a Superintendência de Direitos da Mulher (SUDIM/RJ) dentro da estrutura da Secretaria Estadual de Assistência Social e Direitos Humanos (SEASDH), passou a abranger o Conselho Estadual dos Diretos da Mulher (CEDIM) em sua hierarquia. Nesse ano, a antiga SUDIM assinou o Pacto Nacional de Enfrentamento à Violência Contra Mulher. Esse Pacto definiu as responsabilidades do organismo de Políticas para Mulheres do Estado do Rio de Janeiro como formulação e execução do Projeto Integral Básico. Esse Projeto reúne todas as ações de Prevenção e Combate à Violência Contra as Mulheres realizadas pelos Governo Federal, Estadual e Municipais, ONG`s e Universidades. Ainda nesse período, a SUDIM adotou o conceito de município-polo dentro da perspectiva de descentralização e regionalização de seus programas e serviços.

Dentre os anos de 2007 e 2012, aconteceram as seguintes ações: O número de servidores especializados que prestaram assistência às mulheres vítimas de violência aumentou de 12 (2007) para 34 (2012); a criação de duas DEAMs (São João de Meriti e Nova Friburgo) e dois NUAMs (Petrópolis e Barra Mansa); a estruturação de forma mais adequada do Núcleo de Defesa da Mulher da Defensoria Pública do Estado do Rio de Janeiro; a criação da CEJUVIDA (Centro Judiciária de Abrigamento), no âmbito do Poder Judiciário; o Poder Judiciário criou o Juizado de Violência Doméstica e Familiar Contra as Mulheres; as Instituições de Defesa e Execução de Políticas para Mulheres, como Conselhos, Coordenadorias, Secretarias e Superintendências aumentaram de forma significativa, revelando um compromisso dos Governos Municipais com a promoção dos direitos das mulheres; o aumento do número de unidades de atendimento a mulheres e a melhoria dos equipamentos dessas unidades deve-se à mobilização e à pressão contínua dos movimentos e organizações de mulheres do Estado do Rio de Janeiro; e, vários organismos de políticas para as mulheres e Centros de Referência foram equipados com mobiliário, computadores, televisão, data show e automóveis, através de convênios firmados pela SEASDH com SPM/PR.

Ainda em 2012, realizou-se três cursos para capacitação de cento e quarenta e cinco profissionais de vinte e sete municípios do Estado do Rio de Janeiro que atuam: nos centros especializados de atendimento à mulher em situação de violência; nas Casas Abrigo, na Rede Municipal de Saúde (SMS - Coordenadoria de Prevenção à Dependência Química da Prefeitura do Rio de Janeiro); e, no Judiciário (CEJUVIDA - Central Judiciária de Abrigamento Provisório da Mulher Vítima de Violência Doméstica) e no Legislativo (Disque Assembleia Direitos da Mulher).

Além disso, um Termo de Cooperação foi rescindido, antes mesmo da implementação do serviço (Porto Real) e cinco serviços especializados foram fechados: Barra Mansa, Campos (2), Quissamá e Três Rios. Em 2013, a SUDIM foi extinta com a criação da Subsecretaria de Políticas para as Mulheres (SPMulheres), conferindo maior agilidade administrativa ao organismo responsável por executar as políticas públicas para as mulheres, no Estado do Rio de Janeiro. Essa Subsecretaria foi instituída por meio do decreto 44.076, de 20 de fevereiro de 2013 (assinado pelo governador Sérgio Cabral), como suporte para a Secretaria de Estado de Assistência Social e Direitos Humanos, mantidas as atribuições da Superintendência, sendo o organismo responsável por elaborar e executar as políticas públicas para as mulheres, no Estado do Rio de Janeiro, com o propósito de garantir a cidadania plena da população feminina e o seu empoderamento.

A Subsecretaria supracitada deve sua existência ao enfrentamento à violência contra a mulher, quando na década de 1980, em razão dos assassinatos de mulheres justificados "por amor" e "em defesa da honra", foi criado o Conselho Estadual de Direitos da Mulher (CEDIM), um dos primeiros Conselhos de Direitos da Mulher do país, que era também o órgão executivo de políticas para as mulheres do Estado do Rio de Janeiro. Ainda nessa década já mencionada, anteriormente, foram criados os grupos, SOS Mulher, serviços de atendimento às mulheres vítimas de violência, cujo objetivo era se tornar um espaço de atendimento, reflexão de mudanças nas condições de vida das mulheres vítimas de violência.

A criação dos grupos SOS Mulher é um marco no atendimento direto às mulheres vítimas de violência no Brasil. Foi a partir dessa experiência no Rio de Janeiro que surgiram os primeiros Centros de Atendimento à Mulher em situação de 
violência como serviços governamentais, expressão de política pública. Em 1997, o governo do Estado do Rio de Janeiro entrou, definitivamente, na luta pelo enfrentamento à violência contra a criação de serviços de atendimento às mulheres vítimas. Por força de lei, criou-se o Centro de Atendimento à Mulher (CIAM).

EM 2002, o CIAM Rio tornou-se CIAM Márcia Lyra em homenagem à fonoaudióloga Márcia Maria Lopes Lyra que trabalhou no CEDIM, ela foi estuprada e assassinada em 2001. Em 2008, surgiu o CIAM Baixada e, em 2010, a Casa da Mulher de Manguinhos. Esses serviços eram espaços especializados no atendimento às mulheres vítimas de violência, independentemente do local da ocorrência, da autoria e da tipologia criminal da violência. Orientavam-se por ações globais e de atendimento interdisciplinar (psicológico, social, jurídico de orientação e informação). Ultimamente, apenas o CIAM Márcia Lyra resiste e mantém as qualidades que os outros serviços perderam. Com a criação da Subsecretaria, as políticas para as mulheres ganham na qualificação da gestão e na interlocução com os demais segmentos do governo. Além disso, criou-se duas Superintendências: de Enfrentamento à Contra a Mulher e de Articulação Intersetorial.

No âmbito do município de Seropédica, a Lei no 496 de 17 de dezembro de 2013 que delimita o Plano Plurianual (PPA) para o período de 2014 a 2017, aponta, dentre Ações e Metas Administrativas por Programa de Governo, a existência de recursos na ordem de R\$5 milhões para a Secretaria de Ação Social e Direitos Humanos, sendo que não há registros de vinculação de recursos para qualquer atividade que envolva violência de gênero, violência contra a mulher ou temas correlatos.

No caso do PPA 2018-2021, o valor previsto para a mesma Secretaria de Ação Social e Direitos Humanos, é de R\$7 milhões, em que $\mathrm{R} \$ 2$ milhões é previsto para trabalho de ação social, além de $\mathrm{R} \$ 1,8$ milhão para programa de assistência social comunitária. Não há, pelo menos no PPA, qualquer registro de ações, programas ou projetos associados à temática de violência, violência de gênero, ou qualquer política com foco nas mulheres. No âmbito da Lei Orçamentária Anual (LOA) de 2019, há o destino de R \$1,5 milhão para Assistência Social, já o Fundo Municipal de Assistência Social prevê recursos na ordem de R \$1,6 milhão. Os PPA indicam alto volume de recursos a serem passíveis de aplicação na Assistência Social, todavia, não é demonstrado vinculação ao âmbito de políticas para mulheres. Veja na Tabela 1.

Tabela 1. Orçamento de Assistência Social no PPA 2018-2021 no município de Seropédica.

\begin{tabular}{|c|c|c|c|c|c|}
\hline 08 & $\begin{array}{c}\text { Assistência } \\
\text { social }\end{array}$ & & & & \\
\hline 241 & $\begin{array}{l}\text { Assistência ao } \\
\text { idoso }\end{array}$ & $119.000,00$ & $119.200,00$ & $119.400,00$ & $119.600,00$ \\
\hline 243 & $\begin{array}{l}\text { Assistência à } \\
\text { criança e ao } \\
\text { adolescente }\end{array}$ & $91.000,00$ & $354.800,00$ & $363.400,00$ & $371.800,00$ \\
\hline 244 & $\begin{array}{l}\text { Assistência } \\
\text { comunitária }\end{array}$ & $1.147 .000,00$ & $1.170 .690,00$ & $1.196 .390,00$ & $1.219 .190,00$ \\
\hline Total d & $1.357 .000,00$ & $1.644 .690,00$ & 1.679 . &, 00 & $1.710 .590,00$ \\
\hline
\end{tabular}

Fonte: Lei n ${ }^{\circ} 662$ de 28 de dezembro de 2018, p.184.

O município de Seropédica, através de sites, órgãos e conselhos vinculados as secretarias, não apresenta ter sua gestão em relação aos dados, bem consolidada. Diante disso ocorre uma determinada dificuldade em encontrar informações como Planos Pluri Anuais (PPA), programas e recursos do município referente à mulher ou à violência contra mulher. Entretanto, apesar de tais impedimentos, com analises no site do município e no Portal da Transparência da prefeitura, é possível encontrar informações sobre os PPA recentes. Ainda assim, não apresenta nenhum programa na parte de saúde e segurança referente a 
mulher.

Cabe pontuar que, embora as informações encontradas são inconclusivas e os PPA analisados não possuam dados claros, ao entrar em contato com a prefeitura no portal transparência pelo sistema e-sic, foi fornecido o documento intitulado "Plano Municipal de Saúde de Seropédica" que possuí algumas informações sobre um programa voltado para as mulheres, chamado de "Atenção Integral à Saúde da Mulher", entretanto abrange apenas o período entre 2010-2013 e 2014-2017 e não demonstra indicações sobre recursos aplicados. Ao mesmo tempo, não identificamos no PPA os recursos associados, o que indica que este programa pode estar como parte integrante de políticas de saúde mais amplo.

Tal "Plano Municipal de Saúde de Seropédica", independentemente de prevalecer por dois períodos de planejamento estratégico governamental distintos (2010-2013 e 2014-2017) traz o programa "Atenção Integral à Saúde da Mulher" que possui objetivos, diretrizes e metas parecidas nos dois períodos. Entretanto, o programa se caracteriza pela abordagem relacionada a melhora dos centros hospitalares para exames, oferta de serviços para gestantes, entre outros e nada em relação a violência.

Em relação ao programa previsto para 2010-2013, constatou-se que, os objetivos são elaborados com diretrizes e metas contendo um prazo do mesmo período para serem implantados. Paralelo a isso, no Plano de 2014-2017, apesar de não fornecer informações explicativas sobre Pacto Nacional de Enfrentamento à Violência Contra Mulher, apresenta metas, indicadores e resultados do Pacto em 2012. Destaca-se abaixo as metas referente à mulher e à violência contra a mulher, sejam elas:

1. Ampliar o número de unidades de saúde com serviço de notificação contínua da violência doméstica, sexual e outras violências. Que possuía como indicador - Número de unidades de saúde com serviço de notificação de violência doméstica, sexual e outras violências implantado. (Meta de 3 e realização de 2)

2. Investigar os óbitos em mulheres em idade fértil (MIF). Que possuía como Indicador - Proporção de óbitos de mulheres em idade fértil (MIF) investigados. (A meta não era pactuada, mas realizaram 96,67\%)

A Lei $n^{\circ}$ 272/2005 de 27 de abril de 2005, criou o Conselho Municipal de Seropédica do Direito da Mulher que deveria, segundo a lei, ser instituída pelo poder executivo por meio da Secretaria da Ação Social, Cidadania e Trabalho. A lei não traz as dimensões as quais o conselho de atém. Paralelamente, não há website onde se possa encontrar informações sobre o conselho. Isto demonstra um estado de coisas como apontado por Rua (2009), ao caracterizar momentos de indecisão política ou de falta de informações que permitam tomada de decisão sobre problemas públicos de grande magnitude.

Já a Lei n419/2011 de 26 de dezembro de 2011, criou o Núcleo Integrado de Atendimento à Mulher (NIAM) que é vinculado à Secretaria Municipal de Assistência Social, Direitos Humanos, Trabalho e Renda, de acordo com a orientação da superintendência dos direitos da mulher - SUDIM em atendimento a secretaria de estado e a prefeitura municipal. O NIAM aparenta estar ativo, uma vez que ainda é possível encontrar telefone e e-mail na página da prefeitura de Seropédica. Não obstante, também não há informações específicas do núcleo, website próprio ou páginas online que permita identificar ações do mesmo.

A criação desse núcleo serviu para que o município estivesse em conformidade com a norma técnica de uniformização da secretaria especial de políticas para as mulheres, criada pela lei federal $n^{\circ} 10.683 / 2003$. O NIAM, se tornou a política mais direcionada à violência contra a mulher encontrada, uma vez que, no âmbito da administração pública municipal, é ele que desenvolve alguma forma de prevenção na área de políticas para mulheres, programa, projeto ou ação.

Pode-se constatar também que, como observado no site do IBGE (2018), até o ano de 2018, o município de Seropédica parece não ter conhecimento sobre a própria realidade das políticas para mulheres. O município afirma ao IBGE não possuir abrigos para vítimas de violência contra a mulher, todavia, nos PPA 2013-2017 e 2018-2021, existem menções à 
abrigos sociais (sem mencionar especificamente para vítimas de violência, o que pode ser um problema, pois os abrigos devem possuir caráter anônimo). Ao mesmo tempo, afirma não possuir organismo executivo de políticas para mulheres, o que em parte é falso, já que o NIAM cumpre esta função no âmbito da violência e assistência social. Por outro lado, o município ratifica a não existência de política de priorização de cargos para mulheres em chefia e assessoramento nem de plano municipal de políticas para as mulheres. Veja no Quadro 1 a seguir.

Quadro 1. Verificação de informações sobre políticas para mulheres em Seropédica.

\begin{tabular}{|c|c|}
\hline \multicolumn{2}{|c|}{$\begin{array}{c}\text { AFIRMAÇÕES DA PREFEITURA DE SEROPÉDICA REFERENTE À POLÍTICAS PARA MULHERES EM } \\
\text { QUESTIONÁRIO DO IBGE }\end{array}$} \\
\hline Afirmação & Verificação \\
\hline $\begin{array}{l}\text { Não possui política de priorização de cargos para mulheres em } \\
\text { chefia e assessoramento }\end{array}$ & Não há registros em documentos da prefeitura \\
\hline $\begin{array}{l}\text { Não possui abrigo institucional para mulheres em situação de } \\
\text { violência }\end{array}$ & $\begin{array}{l}\text { Nos PPA 2013-2017 e 2018-2021, existem menções à abrigos } \\
\text { sociais (sem mencionar especificamente para vítimas de violência) }\end{array}$ \\
\hline Não possui organismo executivo de políticas para mulheres & $\begin{array}{l}\text { Em parte, o NIAM cumpre esta função no âmbito da violência e } \\
\text { assistência social }\end{array}$ \\
\hline Não possui plano municipal de políticas para as mulheres & Não há registros em documentos da prefeitura \\
\hline $\begin{array}{l}\text { Não possui Casas - abrigo para atendimento a mulheres em } \\
\text { situação de violência e risco de morte; }\end{array}$ & $\begin{array}{l}\text { Nos PPA 2013-2017 e 2018-2021, existem menções à abrigos } \\
\text { sociais (sem mencionar especificamente para vítimas de violência) }\end{array}$ \\
\hline $\begin{array}{l}\text { O município desenvolve na área de políticas para mulheres, } \\
\text { programa, projeto ou ação em cooperação, convênio e/ou } \\
\text { articulação com } \\
\text { Administração pública municipal }\end{array}$ & O NIAM cumpre esta função \\
\hline Não possui Conselho municipal de direitos da mulher & $\begin{array}{l}\text { Seropédica tem Lei } \mathrm{n}^{\circ} 272 / 2005 \text { de } 27 \text { de abril de } 2005 \text { que } \\
\text { institucionalizou o Conselho }\end{array}$ \\
\hline $\begin{array}{l}\text { Segundo o levantamento quantitativo do IBGE, o município } \\
\text { atendeu em 2017, } 100 \text { mulheres pelo CEAM/CRAM/NIAM para } \\
\text { mulheres em situação de violência }\end{array}$ & Registro pelo IBGE \\
\hline
\end{tabular}

Fonte: Elaborado pelo autor a partir das informações obtidas pelo E-sic, IBGE (2018) e documentos legislativos da prefeitura de Seropédica.

\section{Resultados e Discussão}

A planilha disponibilizada pelo ISP contém 12.430 registros de crimes ocorridos entre $1^{\circ}$ de janeiro de 2006 a 31 de dezembro de 2019 no município de Seropédica. Os crimes cometidos contra mulheres representam 62\% (7.695), contra 34\% (4.273) de homens e foram ignorados 4\%. Em 53\% (6.620) dos casos o crime ocorreu na residência e 28\% (3.475) em via pública. Destes que ocorreram na residência, $72 \%$ (4.746) tiveram as mulheres como vítimas. Em via pública, as mulheres foram $51 \%$ (1.775) das vítimas. No âmbito da relação com a vítima, em $43 \%$ (3.313) das ocorrências em que a vítima foi uma mulher, o agressor é ex, atual companheiro ou cônjuge da vítima e em 15\% (1.125) não há relação. No caso dos homens isso muda de figura, onde observamos que a maior parte dos registros, 30\% (1.279) apontam não existir relação com a vítima, sendo que, em apenas 11\%(476) dos casos, o agressor é ex, atual companheiro ou cônjuge da vítima. Em termos de cor, em 41,43\% (5.150) as vítimas são pardas, 40,67\% (5.055) brancas e 11,35\% (1.411) são negras. Decompondo por gênero e cor, as mulheres são agredidas na seguinte proporção: 43,12\% (3.318) pardas, 42,68\% (3.284) brancas e 1,57\% (885) negras; já os homens: $42 \%$ (1.815) pardos, $41 \%$ (1.747) brancos e $12 \%$ (519) negros.

Em termos de gênero, é possível perceber tendência de aumento de crimes contra as mulheres a partir de 2016 nos 
crimes de ameaça, estupro, lesão corporal, tentativa de homicídio, homicídio doloso, extorsão, sequestro e feminicídio. Até este ano, mulheres e homens tinham registro de queda nos crimes no município de Seropédica, entretanto, a partir deste ano de 2016, os homens têm aumento abrupto proporcional em 2018 e voltam a cair, diferentemente das mulheres, que mantém regularidade no aumento. Ainda assim, as linhas de tendência para homens e mulheres, no geral, era de redução dos índices.

No caso da cor, aparecem as diferenças e podemos verificar trajetória de tendência de aumento de vítimas entre homens e mulheres negros e pardos, com redução para brancos. É possível perceber linha de tendência expressiva de queda na vitimização de pessoas brancas em Seropédica, trajetória de estabilidade de pardos e de crescimento para negros. Referente à conjugalidade, os dados apontam que homens são vitimizados por desconhecidos ou por pessoas sem qualquer relação social, apesar de este índice estar instável de 2006 a 2019.

Em pouquíssimos casos os homens são as vítimas de ex companheiros ou atuais. Diferentemente das mulheres, que são vítimas preferenciais destes dois últimos, apesar de as mulheres serem também mais vítimas de crimes por desconhecidos do que homens em 2019. Devemos incluir, ainda, a dimensão do território, onde podemos verificar que a maior parte dos crimes contra as mulheres acontece na residência (60\% dos casos entre 2006/2019) e em via pública (20-30\% entre 2006/2019), cujos patamares pouco se alteram entre os anos, demonstrando a prevalência da violência nestes dois territórios.

Podemos ressaltar também o enquadramento do crime por legislação. Entre 2006 e parte de 2012, os crimes contra a mulher e sua imputação legal não eram contabilizados pelo ISP. A partir de 2012 começamos a verificar o aumento do enquadramento na Lei Maria da Penha aos poucos e a disputa para reduzir o enquadramento pela lei 9.099/1995 (de menor potencial lesivo) a partir de 2014Estes cinco aspectos de gênero, cor, conjugalidade, territorialidade e enquadramento na legislação podem ser observados nas Figuras 1 a 5 a seguir.

Figura 1. Registro de crimes de ameaça, estupro, lesão corporal, tentativa de homicídio, homicídio doloso, extorsão, sequestro e feminicídio em Seropédica entre 2006 a 2019 por gênero.

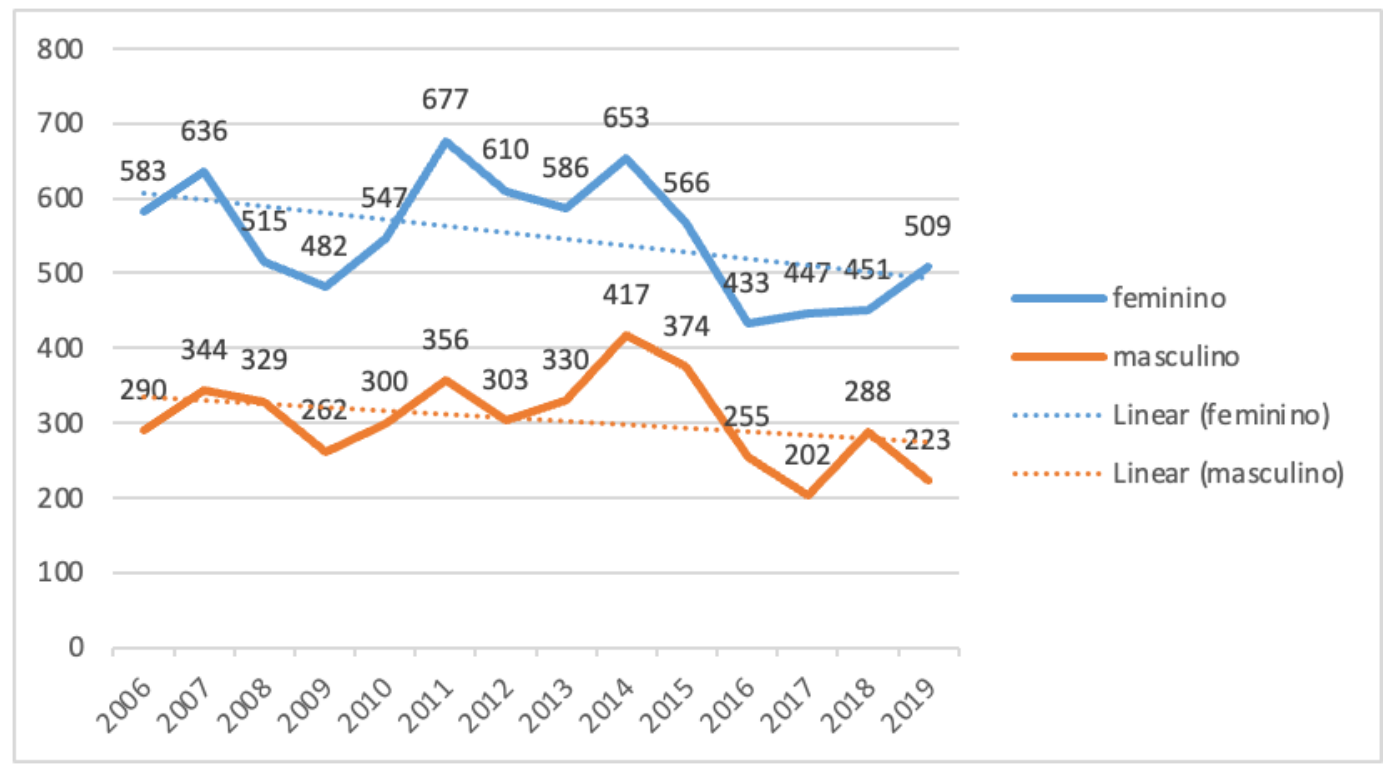

Fonte: ISP (2020). 
Research, Society and Development, v. 11, n. 3, e24611326549, 2022

(CC BY 4.0) | ISSN 2525-3409 | DOI: http://dx.doi.org/10.33448/rsd-v11i3.26549

Figura 2. Registro de crimes de ameaça, estupro, lesão corporal, tentativa de homicídio, homicídio doloso, extorsão, sequestro e feminicídio em Seropédica entre 2006 a 2019 por cor.

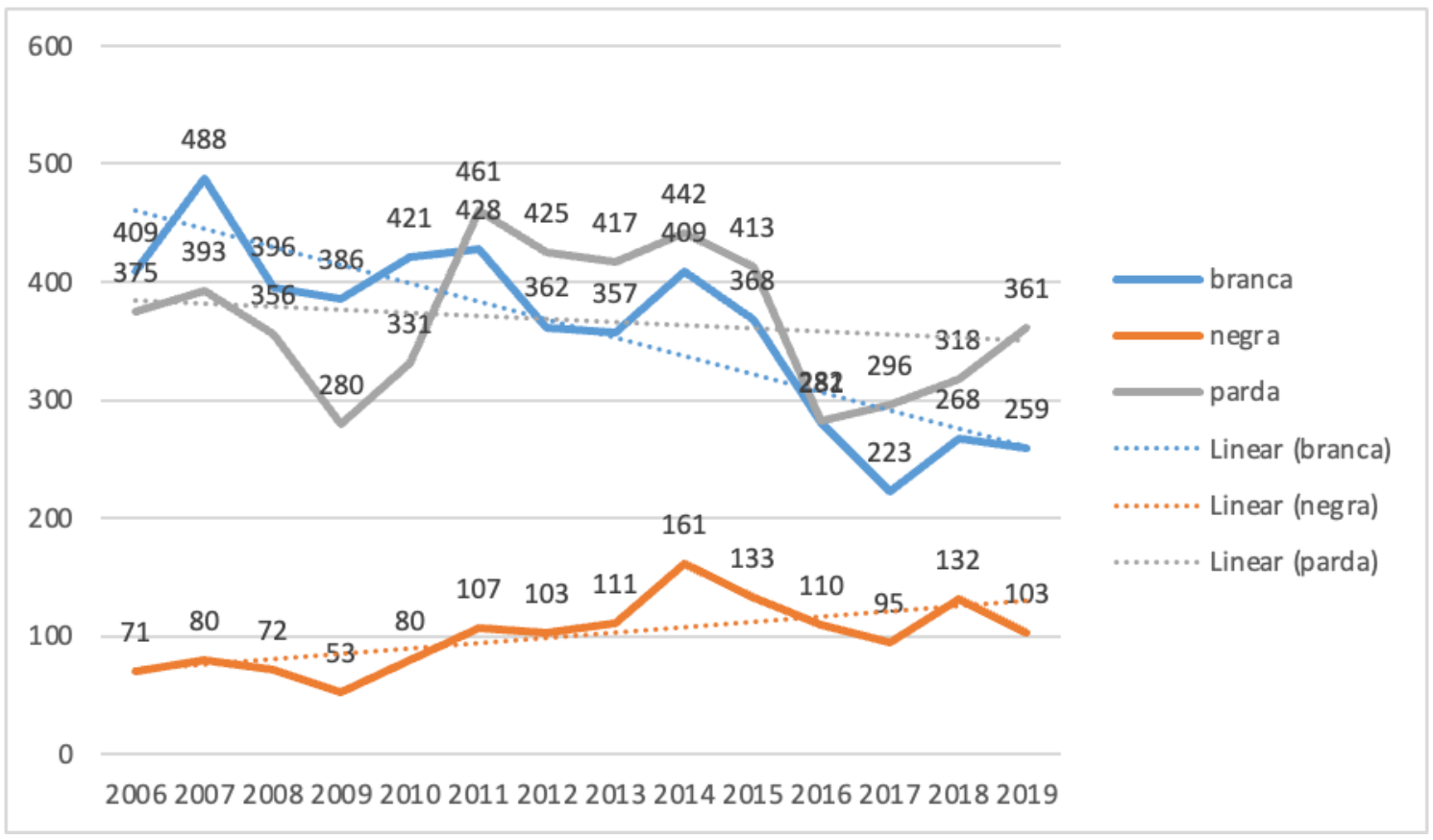

Fonte: ISP (2020).

Figura 3. Registro de crimes de ameaça, estupro, lesão corporal, tentativa de homicídio, homicídio doloso, extorsão, sequestro e feminicídio em Seropédica entre 2006 a 2019 por relação entre autor e vítima (companheiro, ex-companheiro ou nenhuma relação).

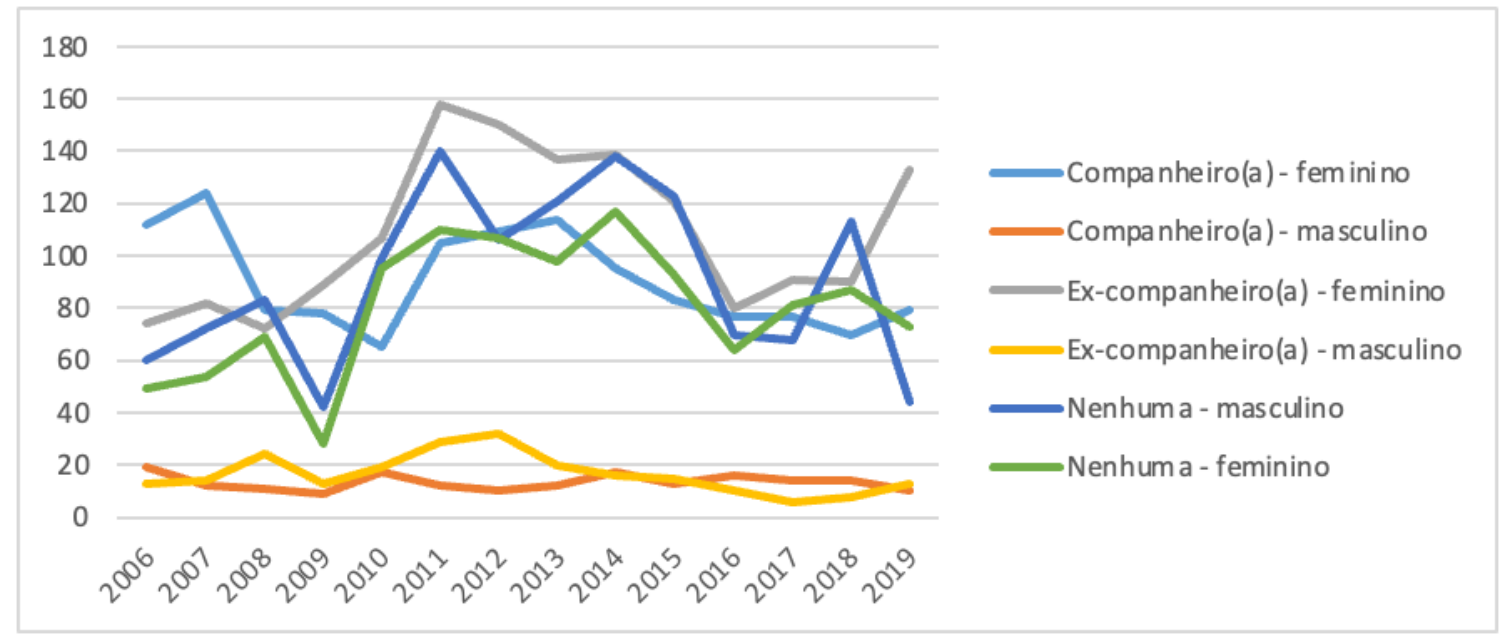

Fonte: ISP (2020). 
Figura 4. Registro de crimes de ameaça, estupro, lesão corporal, tentativa de homicídio, homicídio doloso, extorsão, sequestro e feminicídio em Seropédica entre 2006 a 2019 por enquadramento na Lei.

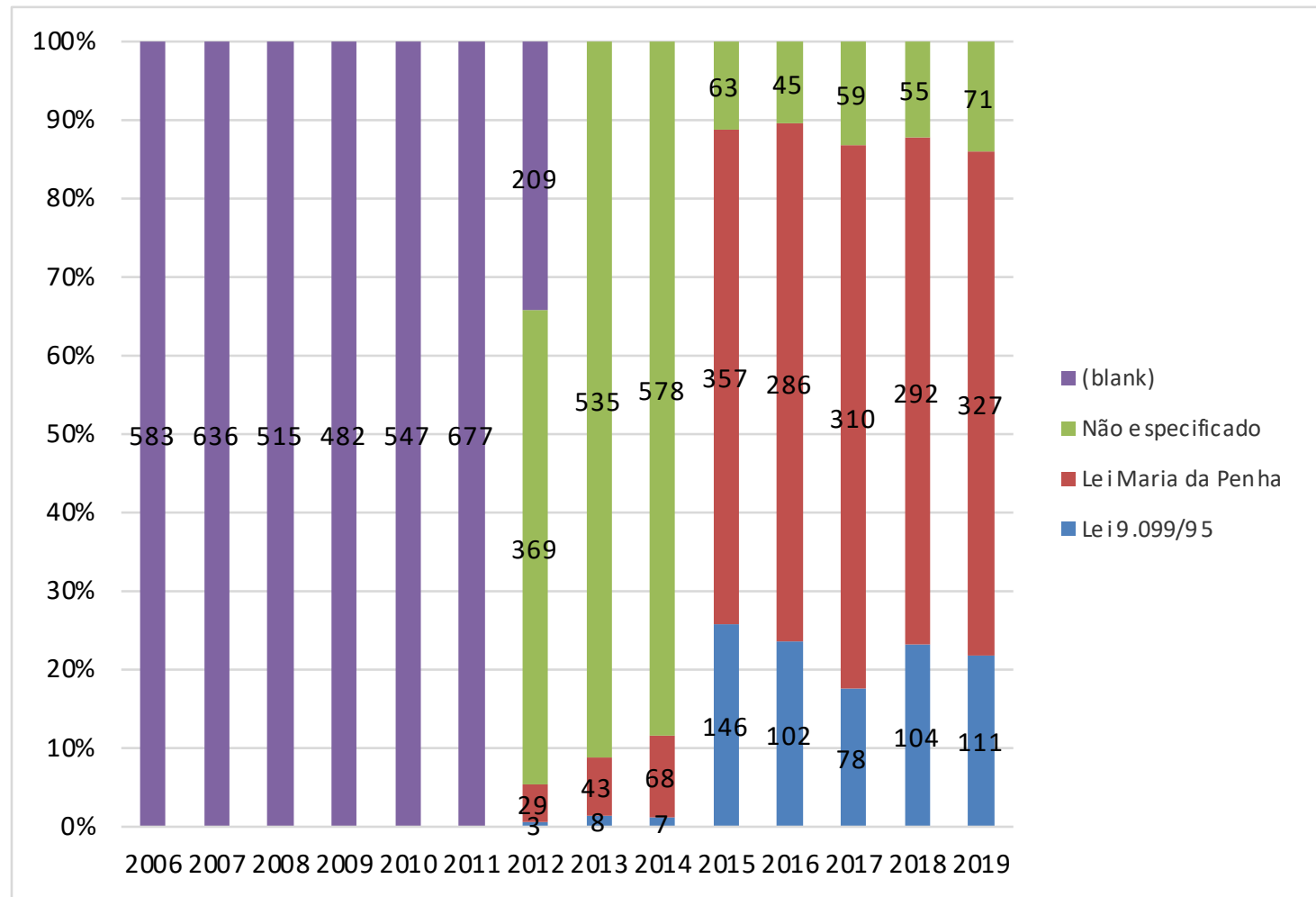

Fonte: ISP (2020). 
Figura 5. Registro de crimes de ameaça, estupro, lesão corporal, tentativa de homicídio, homicídio doloso, extorsão, sequestro e feminicídio em Seropédica entre 2006 a 2019 por local do fato.

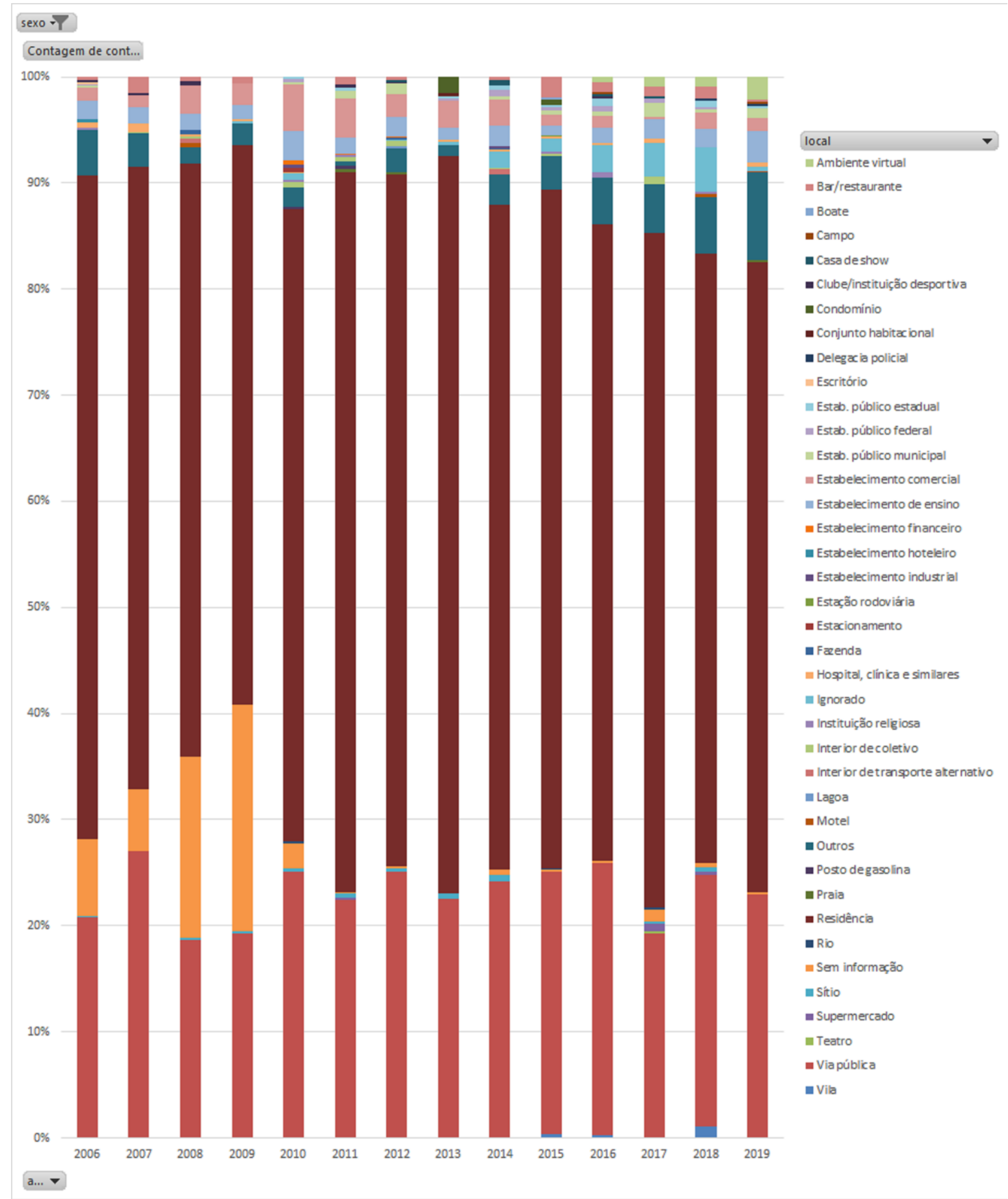

Fonte: ISP(2020).

O objeto de análise recairá nesta parte apenas sobre o ano de 2019. A planilha registra 743 crimes notificados em delegacias entre $1^{\text {o }}$ de janeiro a 31 de dezembro de 2019. Ressaltamos uma questão: a terminologia "negra" costuma agregar dados de mulheres "pretas" e "pardas" (quando não diferenciando), todavia, os dados do ISP utilizam o termo "negros" como sinônimo de "pretos" em alguns casos (como na planilha recebida). Assim, quando existir diferenciação entre "negros" e 
"pretos" nas estatísticas, indicaremos.

Dos 743 crimes registrados, 509 foram cometidos contra mulheres, sendo que 111 (22\%) foram imputados no âmbito da Lei $n^{\circ}$ 9.099/95, que tipifica leis de menor potencial ofensivo, e 327 (64\%) estão registrados no alcance da Lei Maria da Penha. Temos o registro de 71 casos (14\%) sem identificação de lei específica. Este é um dado significativo, tendo em vista que a primeira lei, por tratar de crimes de menor potencial, acaba por possuir punições e medidas protetivas não condizentes com a urgência de proteção à situação de violência contra a mulher. Não há registro de aplicação de Lei do Feminicídio. Neste mesmo aspecto, as mulheres brancas, pardas e negras configuram 37\%, 54\% e 7\% das imputações sob a lei 9.099/95, enquanto que tais percentuais respectivamente no âmbito da lei Maria da Penha são de 36\%, 46\% e 16\%. Esta é uma verificação necessária afim de constatar se existe elemento discriminatório na imputação de crimes por conta da cor, o que não parece ocorrer neste caso.

Dos 509 registros, 302 (59\%) aconteceram na residência da vítima, 117 (23\% em via pública. Destes 302 casos de mulheres vítimas na residência, temos 140 pardas (46\%), 115 brancas (38\%) e 44 negras (15\%). Das 117 vítimas em via pública, temos 59 pardas (50\%), 36 brancas (31\%) e 18 negras (15\%). No caso das mulheres brancas e sua relação com o agressor, que concentram 189 registros, em 76 (40\%) dos casos, o agressor é o ex-companheiro ou atual companheiro e em 54 (29\%) não há relação de parentesco. No caso de mulheres negras, 67 registros, em 35 (52\%) dos casos, o agressor é o excompanheiro ou atual companheiro e em 13 (18\%) não há relação de parentesco. No âmbito das mulheres pardas, 245 registros, em 100 (41\%) dos casos, o agressor é o ex-companheiro ou atual companheiro e em 67 (27\%) não há relação de parentesco. Neste ponto, as mulheres brancas e pardas apresentam semelhanças quando à relação de parentesco, diferentemente das mulheres negras, as quais, de acordo com os dados, são mais agredidas pelos ex-companheiros ou atuais. No geral, $212(42 \%)$ das agressões às mulheres em Seropédica ocorreram pelo ex-companheiro ou atual, e em 138 (27\%) dos casos não há relação entre vítima e agressor.

Quando à profissão da vítima, 105 (21\%) se identificaram como Do Lar, 146 (29\%) como Outros ou Ignorados, 68 (13\%) como Estudantes e 27 (5\%) como desempregadas. O fato de termos 200 (39\%) de casos (do lar, estudante e desempregado) de pessoas cuja ocupação envolve estar um tempo significativo em casa, implica maior potencial de sofrer agressão. Notamos algumas profissões, a exemplo do registro de violência contra Socióloga (branca), microempresária (branca), militar (branca), vereadora (banca), dois registros para desembargadora (parda), ou seja, a violência alcança também profissões que relativamente, possui maiores condições financeiras. Quanto à idade, dos 509 registros, 51 (10\%) entre 0-17 anos, 183 (36\%) entre 18 a 29 anos, 225 (44\%) entre 30 a 49 anos, 40 (8\%) entre 50 a 69 anos, 6 (1\%) com 70 anos ou mais e $4(1 \%)$ sem registro etário.

O ISP também destaca o histograma dos casos de lesão corporal dolosa, estupro e do total das vítimas femininas de Seropédica. No caso da lesão corporal dolosa, as vítimas mais agredidas possuíam idade entre 22 a 28 anos, com registros de vítimas de menos de 1 ano de idade até 82 anos. No caso de estupro, as idades das vítimas variam entre 5 e 25 anos, com casos de mulheres estupradas aos 2 a 10 anos de idade. No âmbito do geral das vítimas, percebemos que a vitimização das mulheres em Seropédica é relativamente jovem, entre 18 a 50 anos de idade, com picos nas faixas etárias de 20 a 30 anos. Tais dados podem ser observados nas Figuras 6, 7 e 8. 
Figura 6. Histograma lesão corporal dolosa em Seropédica no ano de 2019.

Seropédica Vítimas e população por idade - Lesão corporal dolosa

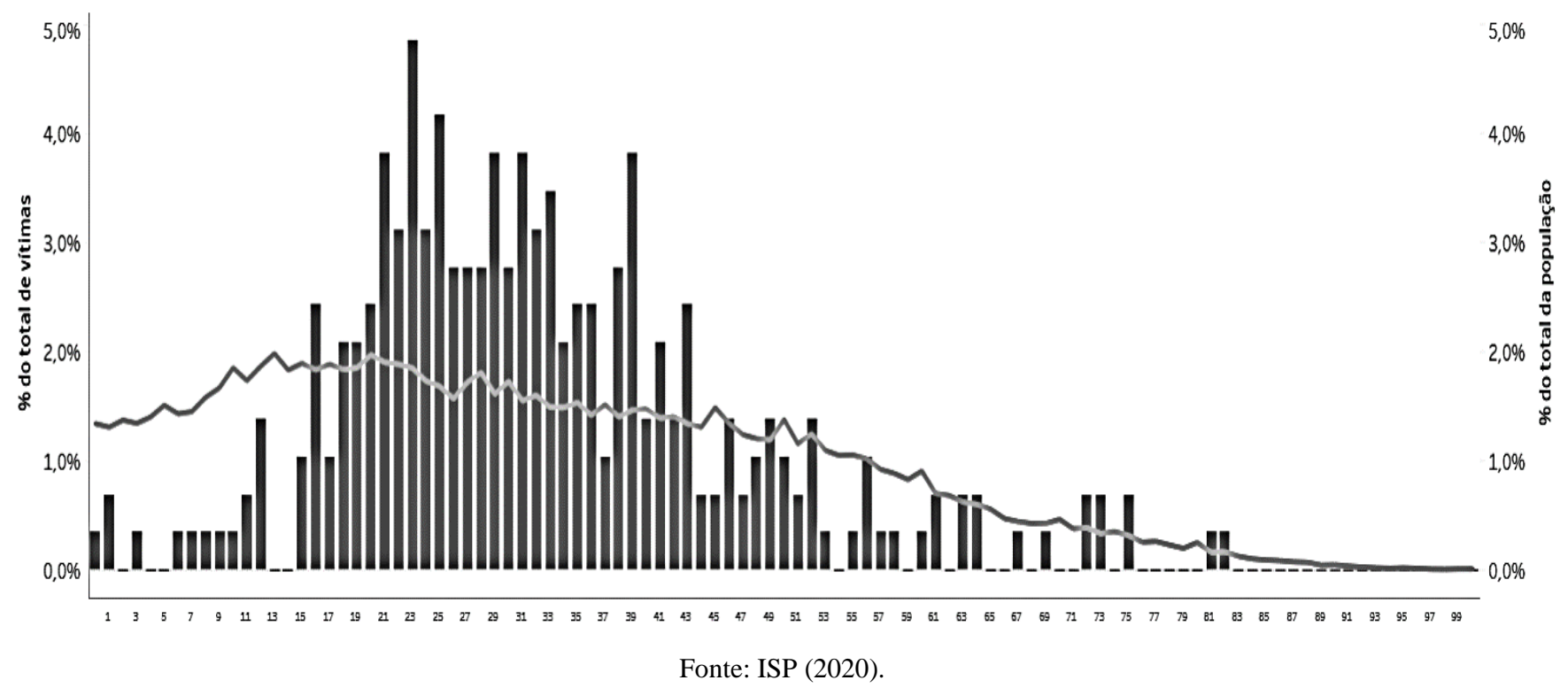

Figura 7. Histograma Estupro em Seropédica no ano de 2019.

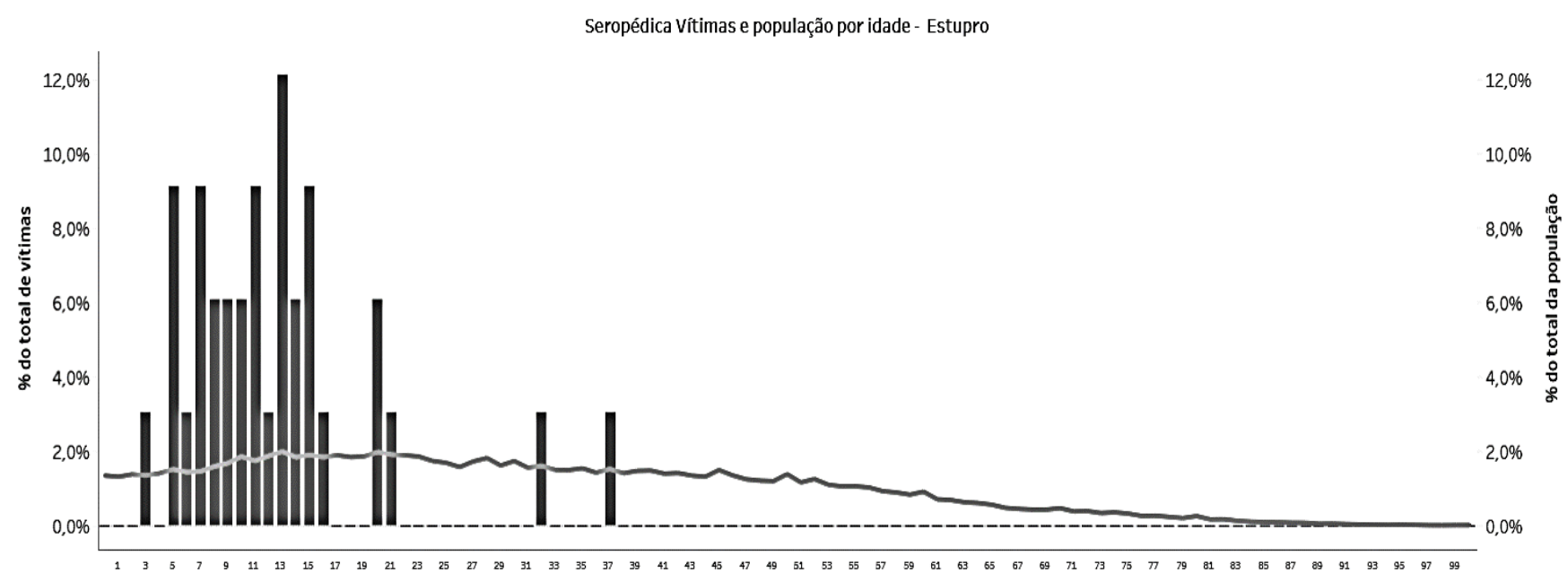

Fonte: ISP (2020). 
Figura 8. Histograma Vítimas e população em Seropédica no ano de 2019.

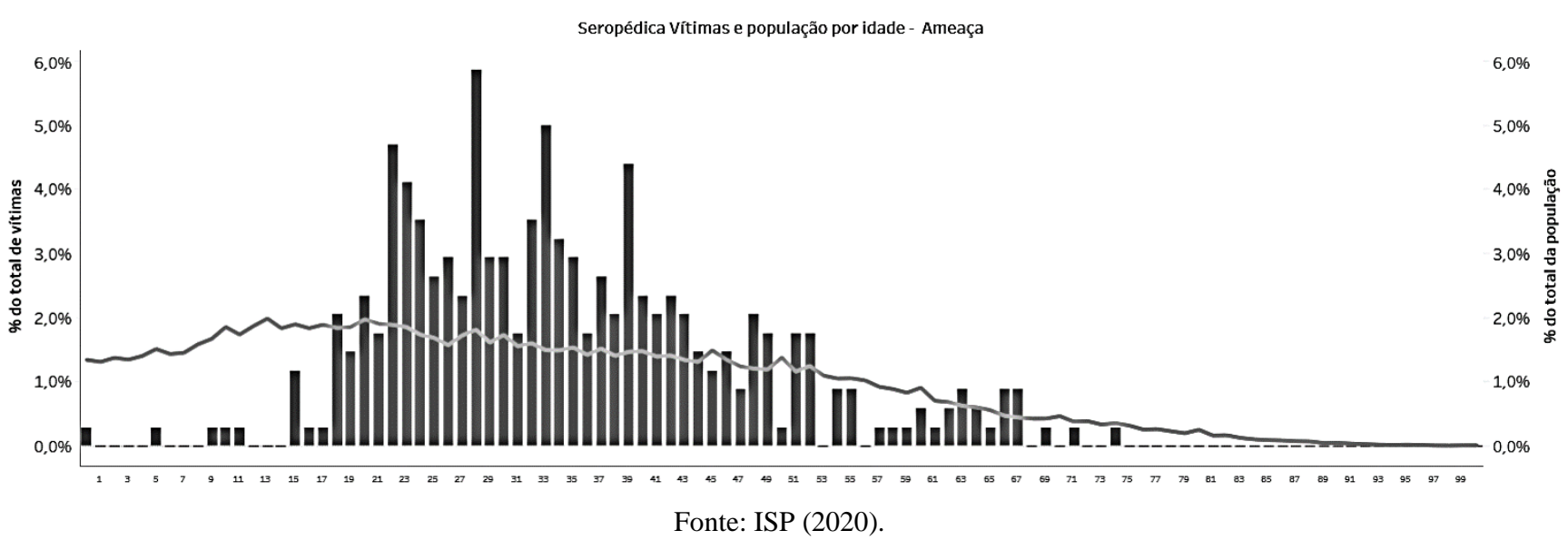

Especificamente, quanto à alguns crimes, Seropédica traz, entre 2017 e 2019 aumento nos casos de Ameaça entre mulheres, passando de 155 em 2017 a 257 em 2019 (aumento de 65\%), enquanto que os homens tiveram aumento de $24 \%$ no mesmo período. No caso de estupros, há relativamente estabilidade nos dados, passando de 29 casos contra mulheres em 2017 para 31 em 2019 (variação de 6\%). Para os homicídios dolosos, há alta proporção de crimes cometidos contra homens, contudo, uma redução de $42 \%$ entre 2018 e 2019. No caso de lesão corporal dolosa, temos redução de $15 \%$ de 2017 para 2019. Ainda assim, as mulheres representam $71 \%$ dos casos de vítimas de lesão corporal dolosa no município de Seropédica em 2019.

Por raça, o aumento dos crimes de ameaça contra mulheres se deu na seguinte proporção entre 2017 e 2019: brancas (121\%), de 57 para 126, pretas (57\%), de 28 para 44, e pardas (66\%), de 103 para 171 vítimas. Apesar de proporcionalmente maior, o crescimento das mulheres pardas ainda é inferior, no conjunto, às mulheres pretas e pardas. No caso dos crimes de estupro: brancas (18\%), de 11 para 13, pretas (0\%), estável em 4 casos, e pardas (13\%), de 15 para 17 vítimas. No caso homicídio doloso: brancas (queda de 66\%), de 9 para 3, pretas (queda de 60\%), queda de 5 para 2, e pardas (queda de 20\%), de 15 para 12 vítimas. Já para lesão corporal: brancas estável em 104 casos, pretas (queda de 19\%), queda de 51 para 41 , e pardas (queda de 1\%), de 139 para 137 vítimas. O que apreendemos é que os crimes de lesão corporal e ameaça vem crescendo entre 2017 e 2019 no município de Seropédica no que se refere à vitimização de mulheres, assim como nos crimes de estupro e lesão corporal dolosa há estabilidade e nos casos de homicídio existe queda nos dados (apesar de homens serem os maiores afetados proporcionalmente neste crime). Observe estes dados nas Figuras 9 a 12 a seguir 
Research, Society and Development, v. 11, n. 3, e24611326549, 2022

(CC BY 4.0) | ISSN 2525-3409 | DOI: http://dx.doi.org/10.33448/rsd-v11i3.26549

Figura 9. Crimes de Ameaça no município de Seropédica entre 2017 e 2019 por raça.

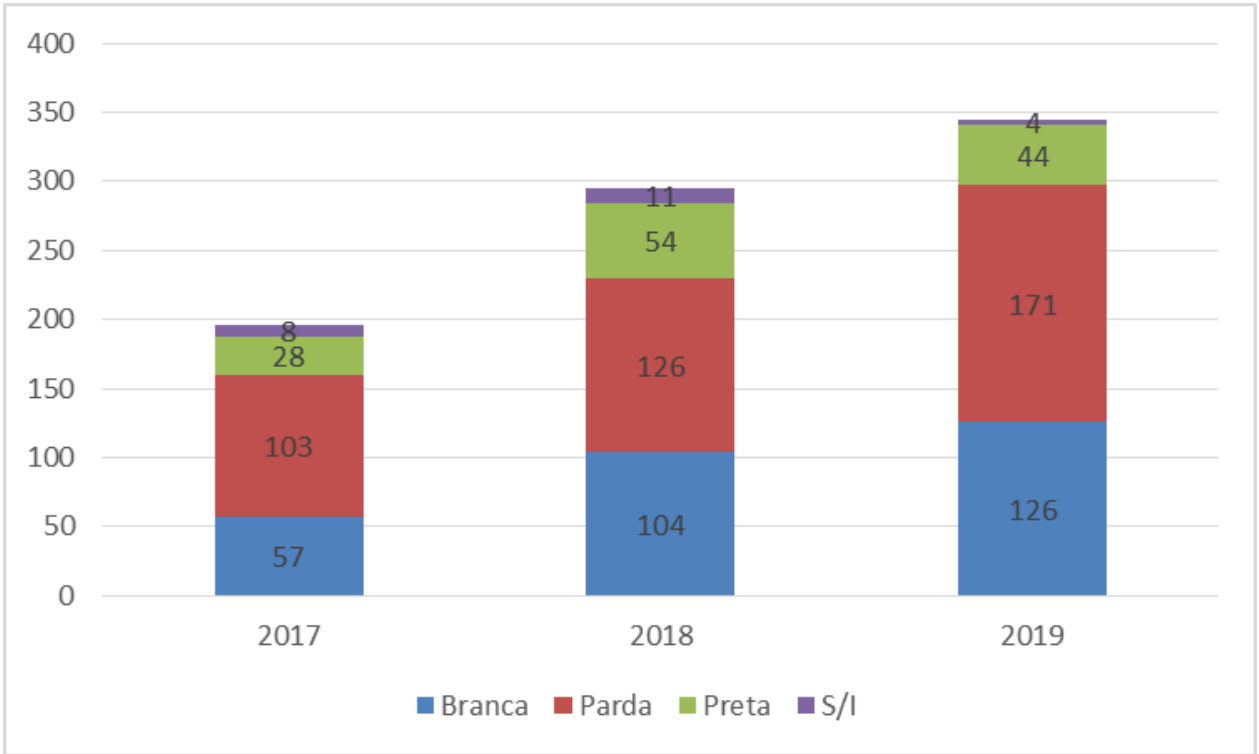

Fonte: ISP (2020).

Figura 10. Crimes de Estupro no município de Seropédica entre 2017 e 2019 por raça.

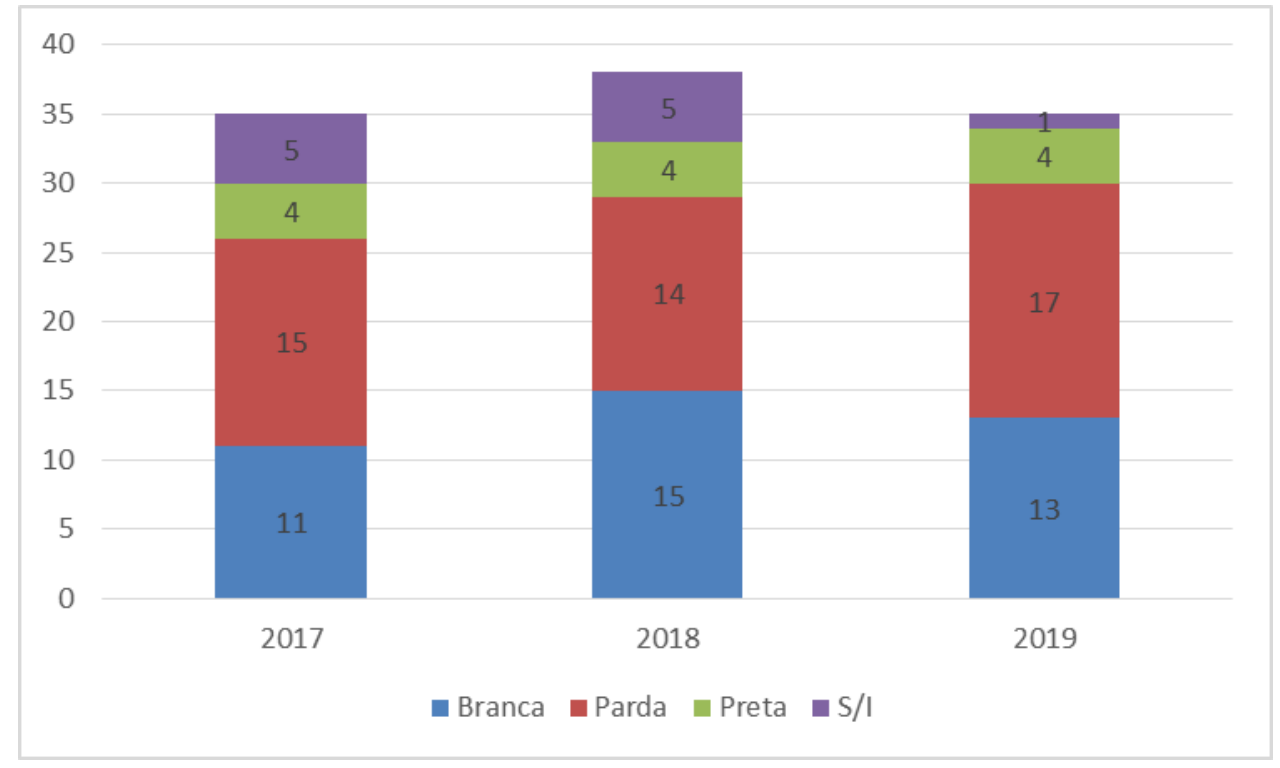

Fonte: ISP (2020). 
Figura 11. Crimes de Homicídio Doloso no município de Seropédica entre 2017 e 2019 por raça.

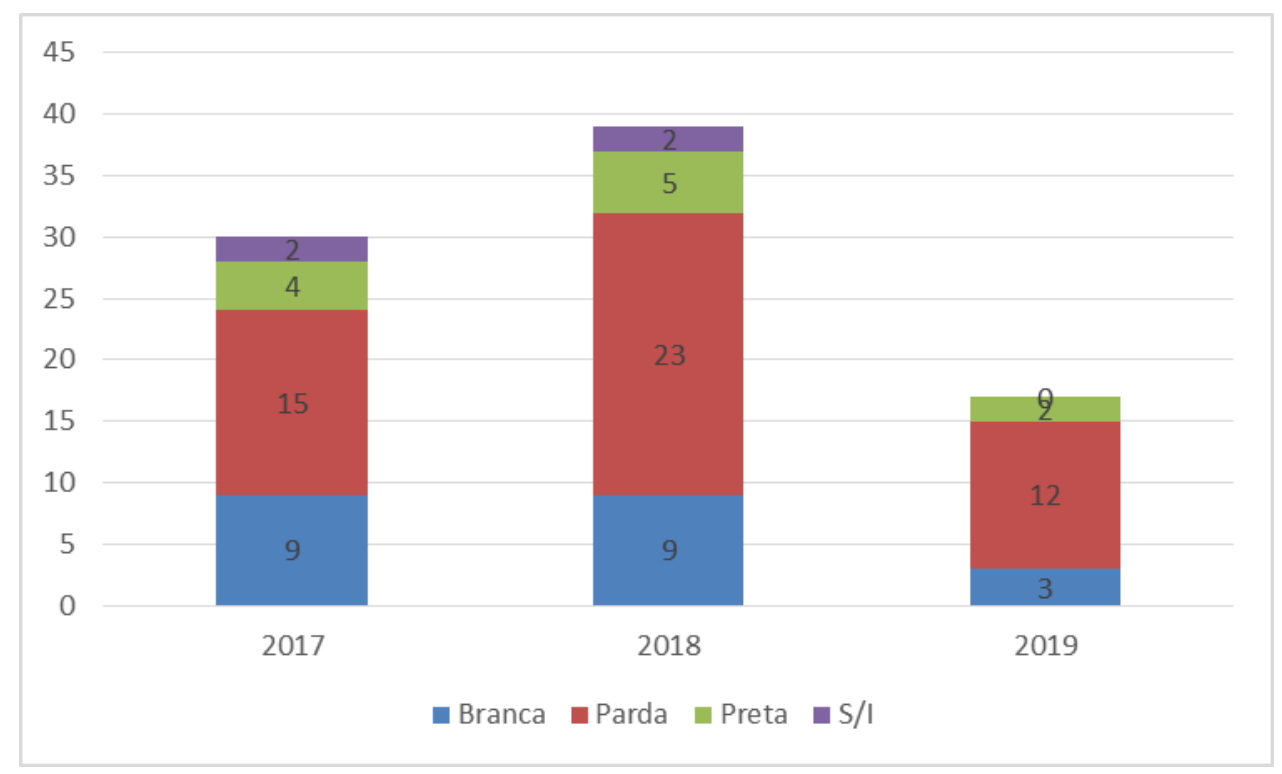

Fonte: ISP (2020)

Figura 12. Crimes de Lesão Corporal Dolosa no município de Seropédica entre 2017 e 2019 por raça.

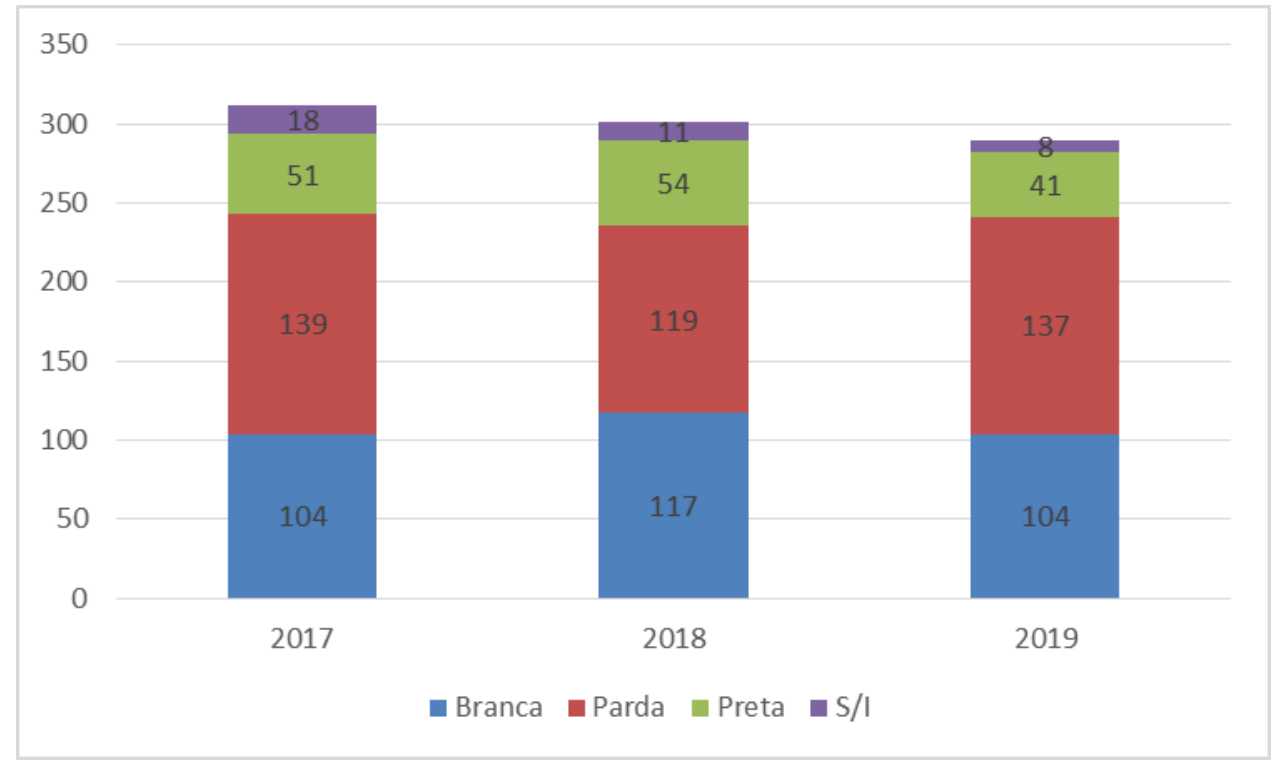

Fonte: ISP (2020).

Por fim, mais um dado a ser ressaltado é que entre 2017 e 2019, o crime de ameaça contra a mulher foi perpetrado pelo ex ou companheiro na média de $47 \%$ dos casos. No caso de estupro, no mesmo período, verificamos uma inflexão: no ano de 2017, 48\% dos agressores não tinha relação com a vítima, o que muda em 2018 em que se observa 38\% dos estupros cometidos por parentes (contra 19\% em 2017) e em 2019, com 41\% cometidos por amigo, vizinho ou conhecido (contra $7 \%$ em 2017 e 6\% em 2018), o que denota que as mulheres vêm denunciando pessoas próximas como autores do crime de estupro. Para o homicídio doloso temos alto número de relações sem registro. No caso de lesão corporal dolosa, o ex ou companheiro respondem na média de 52\% dos casos entre 2017 e 2019. Veja na Tabela 1 a seguir. 
Tabela 2. Relação entre vítima e autor por crime entre 2017 e 2019 no município de Seropédica.

\begin{tabular}{|c|c|c|c|c|c|}
\hline \multicolumn{6}{|c|}{ Relação com a vítima } \\
\hline Crime & $\begin{array}{c}\text { Ex ou } \\
\text { companheiro }\end{array}$ & $\begin{array}{c}\text { Amigo, vizinho } \\
\text { ou conhecido }\end{array}$ & Parentes & Nenhuma & $\mathrm{S} / \mathrm{I}$ \\
\hline \multicolumn{6}{|c|}{2017} \\
\hline Ameaça & $46 \%$ & $5 \%$ & $17 \%$ & $26 \%$ & $6 \%$ \\
\hline Estupro & $7 \%$ & $7 \%$ & $19 \%$ & $48 \%$ & $19 \%$ \\
\hline Homicídio Doloso & $0 \%$ & $0 \%$ & $0 \%$ & $7 \%$ & $93 \%$ \\
\hline Lesão Corporal dolosa & $54 \%$ & $3 \%$ & $15 \%$ & $22 \%$ & $6 \%$ \\
\hline \multicolumn{6}{|c|}{2018} \\
\hline Ameaça & $42 \%$ & $9 \%$ & $11 \%$ & $28 \%$ & $9 \%$ \\
\hline Estupro & $12 \%$ & $6 \%$ & $38 \%$ & $32 \%$ & $12 \%$ \\
\hline Homicídio Doloso & $0 \%$ & $0 \%$ & $8 \%$ & $22 \%$ & $70 \%$ \\
\hline Lesão Corporal dolosa & $51 \%$ & $3 \%$ & $14 \%$ & $25 \%$ & $8 \%$ \\
\hline \multicolumn{6}{|c|}{2019} \\
\hline Ameaça & $55 \%$ & $10 \%$ & $8 \%$ & $19 \%$ & $9 \%$ \\
\hline Estupro & $7 \%$ & $41 \%$ & $31 \%$ & $14 \%$ & $7 \%$ \\
\hline Homicídio Doloso & $0 \%$ & $0 \%$ & $0 \%$ & $0 \%$ & $100 \%$ \\
\hline Lesão Corporal dolosa & $51 \%$ & $7 \%$ & $15 \%$ & $16 \%$ & $11 \%$ \\
\hline
\end{tabular}

Fonte: Elaborado a partir de ISP (2020).

Os dados obtidos junto ao ISP e relacionados com o Estado do Rio de Janeiro, indicam algumas conclusões: primeiramente, ratificam a ideia do lar ou ambiente doméstico como espaço social potencial para vitimização da mulher. Ao mesmo tempo, em crimes específicos como ameaça e lesão corporal dolosa, indicam que ex ou companheiros são agressores em potencial, o que não afasta o crescimento em momentos especiais, de agressores como parentes.

Outra possível conclusão é que a vítima, em boa parte dos casos, possui vínculo com o agressor. Este ponto é fundamental para se evitar conclusões tautológicas no sentido de que se uma violência acontece na residência, tem relação direta de vínculo entre agressor e vítima sem necessariamente destrinchar os dados para averiguar tal afirmação. Os dados obtidos pelo ISP orientam para a conclusão de que os crimes acontecem em casa e que os potenciais agressores possuem vínculos com a vítima (o que é perceptível nos casos do estado do Rio de Janeiro e no município de Seropédica.

Os dados indicam que as mulheres solteiras e em idade produtiva (18 a 39 anos) são vítimas em potencial de agressões (nos crimes analisados), o que não afasta as relações de parentesco e conjugalidade. No caso do município de Seropédica, as vítimas em potencial (80\%) possuem idade entre 18 a 49 anos, cujas ocupações (Do Lar, estudante, desempregado) são associadas com o ambiente doméstico, estando mais vulneráveis à potencial violência.

Um dado que nos chamou atenção na violência no Estado do Rio de Janeiro se refere à escolaridade, onde percebemos que existe relação inversa: quanto mais escolaridade alcança ensino superior, menos denúncias. Isso poderia indicar que as mulheres mais escolarizadas estariam menos vulneráveis à violência (o que é implausível, em um primeiro momento, já que notamos classes superiores sendo agredidas nos dados de Seropédica). Por outro lado, poderia existir a questão do silenciamento, como se a agressão contra a mulher fosse apenas para mulheres "não informadas", não escolarizadas, que estariam mais vulneráveis à violência.

Neste ponto, destacamos que o município de Seropédica não indica qualquer ação direta no enfretamento ou de 
criação de políticas frente a violência contra a mulher até 2019 (apesar de indicar isto em seu Plano Municipal de Saúde e fazer parte de uma rede do Conselho Estadual dos Direitos da Mulher). O município indica possuir um núcleo de atendimento à mulher, mas que não é passível de identificação nos meios oficiais, assim como seu Conselho Municipal do Direito da Mulher. Paralelamente, ao responder indagações do IBGE, o município de Seropédica parece desconhecer sua própria realidade. Este ponto é importante, pois, apesar o município aparentar possuir uma ou outra forma de tratamento público sobre as questões da violência, não apresenta medidas de fato de intervenção sobre a realidade. Ainda que possa possuir um abrigo inscrito em seus planos governamentais (este é para abrigamento de crianças e idosos), este não é orientado para políticas de violência de gênero.

A questão da violência contra a mulher depende de informação. Seja para denúncia, seja para compreensão do sentido da violência, seja para entender que aqueles com os quais mais se têm contato, quando agridem, não caracteriza um aspecto momentâneo, mas condiz à agressão de fato. Percebemos que ao obter informação, casos de estupro que geralmente possuem identificação do agressor como "não informado" vem sendo reduzidos e, cada vez mais surgem identificações associadas ao "ex ou atual companheiro" ou parentes. Ou seja, as mulheres percebem seus cônjuges ou ex como agressores de fato e reúnem coragem para realizar a denúncia, independente da "santidade" do lar, onde o Estado não alcança.

Este último ponto talvez seja o mais importante que caracteriza a violência contra a mulher: este tipo de violência, na maior parte dos casos, acontece na própria residência da vítima e tem, em certos crimes tem um rosto definido, com o agressor convivendo sob o mesmo teto. Portanto, este trabalho, por meio de dados e descrição dos cenários do Estado do Rio de Janeiro e do Município de Seropédica, procurou demonstrar uma caracterização estratificada que permita situar elementos necessários para melhorar as formas como as estatísticas de violência contra a mulher são produzidas.

Aqui, de fato, para concluir, nos deparamos com problemas do próprio Instituto de Segurança Pública, que apresenta dados relativos a 2014-2017 de uma distribuição e a partir de 2017, de outra forma, em que o pesquisador da área precisa realizar esforço de organizar os dados que, em boa parte, não estão tabulados da mesma forma nem possuem coleta de dados no longo prazo. Para delimitar a real situação da violência contra a mulher são necessários dados estratificados por idade, escolaridade, cor, renda, ocupação, local do fato, relação com o agressor, meio empregado, dentre outras informações que nos permitam construir perfis de vítimas, sem essencializar a ideia de que toda mulher tem a mesma probabilidade de ser agredida.

\section{Considerações Finais}

A violência contra a mulher é configurada como problema público a partir de três perspectivas aqui situados: 1) historicamente construído em mecanismos de subordinação, assujeitamento e dominação; 2) saúde pública, enquanto constante epidêmica de altos índices que colocam o Brasil como um dos locais mais propícios à violência de gênero; 3) violação de direitos humanos calcado na base estrutural da ordem social.

A violência de gênero se demonstra uma perspectiva que demanda estatísticas e dados consolidados de forma estratificada. Este processo evita essencialização e a errônea compreensão de que violência de gênero seja sinônimo de violência contra a mulher. Como os dados do estado do Rio de Janeiro e do município de Seropédica demonstraram, a violência atinge homens e mulheres de formas distintas. Como indicado por Garcia (2016), os homens predominam, tanto como vítimas, quanto como perpetradores da dimensão da violência. Este elemento duplo implica considerar os contextos das relações de gênero que constroem e onde se dão estas violências.

A violência contra a mulher é uma forma de violência de gênero, e que se configura pela proximidade da relação entre a vítima e agressor, além de sua "invisibilidade" do local em que ocorre: o lar ou a residência da vítima. Esta invisibilidade é uma característica da violência contra a mulher que incide sobre a produção dos dados que orientam a construção das políticas de combate. Não obstante, a violência contra a mulher se solidifica pela moralidade com a qual é tratada: às mulheres cabe o 
"papel" de "decidir" se comprometem a estrutura familiar ou das relações familiares quando uma violência acontece; isto posto, há de se considerar, portanto, as condições de dependência criadas nas relações familiares que impedem as denúncias de violência ocorridas no ambiente doméstico.

Como destacado pelos dados, existem dimensões que caracterizam a violência contra a mulher no estado do Rio de Janeiro e do município de Seropédica: uma delas aponta sobre pessoas cuja ocupação envolve estar um tempo significativo em casa (do lar, estudantes e desempregadas), o que implica maior potencial de sofrer agressão. Isto não significa que mulheres de ocupações de maior remuneração não sejam atingidas, aa exemplo do registro de queixas de sociólogas e desembargadoras, por exemplo. Ao mesmo tempo, crimes contra mulheres pardas e brancas vêm assumindo trajetória de redução, enquanto o de mulheres pretas crescem entre 2006 e 2019. É clara, portanto, a interseccionalidade entre classe e gênero na violência em Seropédica.

Por fim, a violência contra a mulher tem uma característica ainda mais específica: a de possuir um rosto. A relação entre vítima e agressor é conhecida. Aqui existem duas implicações: 1) a relação de subordinação, propriedade e honra; 2) a resistência à moralidade da violência.

Quanto ao primeiro aspecto, devemos afastar a possibilidade de que as manifestações da violência contra a mulher na perspectiva dos crimes de honra tenham sido eliminadas por conta de dispositivos legais não compreenderem mais esta justificativa no ato criminoso. O que vemos, pelos dados, é que ainda existe a dimensão de propriedade sobre o corpo e da relação social que orienta a ação de companheiros, ex-companheiros, cônjuges e ex-cônjuges na prática dos crimes contra a mulher. A justificativa para a defesa legal pode ter sido eliminada, mas a fundamentação ao ato criminoso, não.

O segundo aspecto é mais complexo e representa um processo de conscientização sobre a construção política da violência contra a mulher e da violência de gênero. A produção de conteúdo, estatísticas e informativos sobre a violência acabam por prover às mulheres a informação de que devem denunciar as formas de violência a que venham a ser submetidas. Ao mesmo tempo, que não existem "graus" de violência, mas formas, como as cinco previstas na Lei Maria da Penha. Paralelamente, é posto à prova, o papel "moral" das mulheres em manter as aparências de um ambiente doméstico em que ocorra a violência, ou seja, a conscientização implica desconstruir a dimensão de que cabe o lugar de subordinação e "respeito" às instituições familiares que envolvem a família.

Ainda há de se considerar as incongruências do município de Seropédica: apresenta Núcleo de Atendimento à Mulher, assim como um Conselho de Direitos da Mulher (ainda que não encontremos sites específicos, nem atas, nem qualquer tipo de informação que não seja um e-mail ou telefone de contato). No próprio site do IBGE aparece a informação de que o município não possui conselho nem núcleo (mas existem leis sancionadas sobre a matéria e que não foram revogadas). Ou seja, o município informa ao órgão federal que não tem instituições, mas destaca a existência das leis em seus sites governamentais.

Destacamos que os dados, as instituições e os programas falam: existe um contexto claro de violência que não é objeto de consideração nem de intervenção do Estado (neste caso, do município), ao passo em que existem mecanismos institucionais de mera "aparência" governamental. Ou, ao menos, existe crítica dubiedade do município em afirmar a existência de instituições governamentais quando não se encontra qualquer manifestação clara de acompanhamento, dados ou documentação das ações de violência contra a mulher. As instituições, dados e programas falam: cabe então interpretar.

Neste sentido, pretendemos demonstrar, por dados e construção teórica, a base do perfil de violência em um município do estado do Rio de Janeiro afim de que esta temática entre na Agenda dos gestores de políticas públicas e que permitam debates para a Agenda decisória para ações do Estado frente esta questão de interesse público, que é a violência contra a mulher, como uma manifestação de violência de gênero. Não obstante, recomendamos como estudos futuros análise estratificada que considere impacto de renda, ocupação, escolaridade e territorialidade, pois entendemos a violência como fenômeno social e que se desenvolve no âmago da estrutura social. 


\section{Referências}

Araujo, M. F. (2008). Gênero e violência contra a mulher: o perigoso jogo de poder e dominação. Psicologia para América Latina, 14: 0-0.

Baptista, V. F. (2021a). Reconhecimento de direitos de pessoas trans: alternativas, políticas e ativismo teórico-judicial. Revista de Direito Brasileira, 28: 131163.

Baptista, V. F. (2021b). Justicia, Familia y Cuidado: Apuntes Normativos en Políticas Públicas. Revista Chilena de Derecho del Trabajo y de la Seguridad Social, v. 12, p. 1-26.

Baptista, V. F \& Santos, W. C. (2021c). Territórios, políticas e manipulações: a segurança pública no olhar da letalidade violenta no Estado do Rio de Janeiro. Revista Política e Planejamento Regional, 8: 377-401.

Baptista, V. F. (2020). The critique of justice in the debate between Nancy Fraser and Axel Honneth: notes toward a critical theory. Revista Argentina de Ciencia Política, 1: 37-62.

Baptista, V. F. Violência contra à mulher e perspectivas de ações programáticas: o sentido estrutural da violência direta e indireta. Gênero \& Direito, 8(3): 214-236.

Bandeira, L. M. (2014). Violência de gênero: a construção de um campo teórico e de investigação. Sociedade \& Estado, Brasília, 29(2):449-469.

Barufaldi, L. A. et al. (2017). Violência de gênero: comparação da mortalidade por agressão em mulheres com e sem notificação prévia de violência. Ciência \& Saúde Coletiva, 22(9): 2929-2938.

Battisti, C. R. \& Lohmann, P. M. (2020.) Análise dos indicadores de violência contra a mulher provenientes das notificações de violência da $16^{\mathrm{a}}$ Coordenadoria Regional de Saúde. Research, Society and Development, 9(2): 1-20.

Cordeiro, N. J.S. et al. A violência intrafamiliar e os reflexos na educação: uma proposta ou um desafio para a cultura de paz. Research, Society and Development, 9(6): 1-17.

Garcia, L. P. (2016). A magnitude invisível da violência contra a mulher. Epidemiologia e Serviços de Saúde, 25(3): $451-454$.

Instituto Brasileiro de Geografia e Estatística [IBGE]. (2018). Perfil dos Municípios (Seropédica).

Lima, L. A. A. et al. (2016). Marcos e dispositivos legais no combate à violência contra a mulher no Brasil. Revista de Enfermagem Referência, 4(11): 139146.

Michau, L. et al. (2015). Prevention of violence against women and girls: Lessons from practice. The Lancet, 385(9978): 1672-1684.

Richardson, R. J. et al. (2007). Pesquisa social: métodos e técnicas. 3. ed. rev. ampliada. São Paulo: Atlas.

Saffioti, H. (2004). Gênero, patriarcado, violência. São Paulo: Fundação Perseu Abramo.

Saffioti, H; Almeida, S. (1995). Violência de gênero: poder e impotência. Rio de Janeiro: Revinter.

Scott, J. (1998). Gender and the Politics of History. New York: Columbia University Press.

Sebaldeli, A. C. G.; Ignotti, E. \& Hartwig, S. V. (2021). Violência contra a mulher em uma cidade da fronteira do Brasil. Research, Society and Development, 10(3): 1-14

Segato, R. (2003). Las estructuras elementales de la violencia: ensayos sobre gênero entre antropologia, psicoanálisis y derechos humanos. Buenos Aires: Prometeo.

Seropédica [Município]. (2019). Lei nº 662 de 28 de dezembro de 2018. Institui o Plano Plurianual da Administração Pública Municipal para o período de 2018 a 2021 e dá outras providências. Diário Oficial de Seropédica de 9 de fevereiro de 2019.

Seropédica [Município]. (2019). Lei n 661 de 8 de janeiro de 2019. Estima a receita e fixa a despesa do município de Seropédica para o exercício de 2019. Diário Oficial de Seropédica de 8 de janeiro de 2019.

Seropédica [Município]. (2014). Lei no 496 de 17 de dezembro de 2013. Institui o Plano Plurianual da Administração Pública Municipal para o período de 2014 a 2017 e dá outras providências.

Seropédica [Município]. (2011). Lei no 419 de 26 de dezembro de 2011. Dispõe sobre criação do Núcleo Integrado de Atendimento à Mulher - NIAM.

Seropédica [Município]. (2005). Lei no 272 de 27 de abril de 2005. Cria o Conselho Municipal de Seropédica do Direito da Mulher.

Silva, A. F. C. et al. (2020). Violência doméstica contra a mulher: contexto sociocultural e saúde mental da vítima. Research, Society and Development, 9(3): 1-17.

Silva, B. C.; Ramos, E. M. L. S. \& Souza, J. C. (2020). A violência virtual contra vítimas mulheres de Belém/Pará. Research, Society and Development, 9(8): $1-20$.

Steiner, H. (2000). International Human Rights in Context: Law, Politics and Morals. Second edition, Oxford: Oxford University Press.

White, M. \& Satyen, L. (2015). Cross-cultural differences in intimate partner violence and depression: A systematic review. Aggression and Violent Behavior, 24: $120-130$. 
Research, Society and Development, v. 11, n. 3, e24611326549, 2022

(CC BY 4.0) | ISSN 2525-3409 | DOI: http://dx.doi.org/10.33448/rsd-v11i3.26549

World Health Organization (WHO). (2013). Global and regional estimates of violence against women prevalence and health effects of intimate partner violence and non-partner sexual violence. Geneva: WHO.

Young, I. M. (1990). Justice and the politics of difference. Princeton: Princeton University Press,

Young I. M. (2010). Inclusion and democracy. New York: Oxford University Press.

Young, I. M. (2011). Responsability for justice. New York: Oxford University Press. 